\title{
High levels of serum $\beta 2$-microglobulin predict severity of coronary artery disease
}

Ling You ${ }^{1 \dagger}$, Ruiqin Xie ${ }^{1 \dagger}$, Haijuan Hu${ }^{1}$, Guoqiang Gu${ }^{1}$, Hongmei Zheng ${ }^{1}$, Jidong Zhang ${ }^{1}$, Xiaohong Yang ${ }^{1}$, Ximiao $\mathrm{He}^{2^{*}}$ and Wei Cui ${ }^{1^{*}}$

\begin{abstract}
Background: The identification of new risk factors for coronary artery disease (CAD) is increasingly sought in an effort to tackle this threatening disease. $\beta 2$-microglobulin (B2M) is reported to associate with peripheral arterial disease and adverse cardiovascular outcomes. However, the association between B2M and cardiovascular disease remains under-researched. This study evaluated the effects of B2M on CAD without renal dysfunction.
\end{abstract}

Methods: One thousand seven hundred sixty-two subjects (403 non-CAD subjects and 1,359 CAD subjects) were investigated. Fasting samples were collected to determine B2M level. The Gensini and SYNTAX scores were used to assess the severity of CAD.

Results: CAD subjects were significantly higher in serum B2M level comparing with non-CAD subjects (1.25 \pm 0.46 vs $1.14 \pm 0.28 \mathrm{mg} / \mathrm{L}, p<0.001)$. Serum B2M level was a risk factor of CAD after adjusting potential confounders (Odds Ratio $(\mathrm{OR})=2.363,95 \%$ confidence interval $(C \mathrm{Cl})$ : 1.467-3.906, $p=0.001$ ). Receiver operating characteristics (ROC) showed B2M level moderately predicted diagnosis of CAD (the area under the ROC curve $(A \cup C)=0.608$, $95 \%$ Cl: $0.577-0.639, p<0.001)$. Furthermore, serum B2M level was positively associated with Gensini score system, SYNTAX score system and the number of disease vessels (NDV $\geq 2$ ).

Conclusions: The significant association between serum B2M and CAD suggests that B2M could be a biomarker for CAD.

Keywords: $\beta 2$-Microglobulin, Severity, Coronary artery disease

\section{Background}

Coronary artery disease $(\mathrm{CAD})$ has remained the first death burden globally between 2000 and 2012. It was responsible for over 7.4 million deaths in 2012. Although, both genders of all ages may develop CAD, males and the elderly are more vulnerable to death causing by CAD $[1,2]$. Quality of life was also remarkably reduced in CAD patients. Nearly a third patients had angina attacks at least once per week [3]. Therefore, there is imperative focus to identify new CAD risk factors. Several biomarkers, such as C-reactive protein $[4,5]$, natriuretic

\footnotetext{
* Correspondence: Ximiao.He@gmail.com; cuiwei@medmail.com.cn ${ }^{\dagger}$ Equal contributors

2Laboratory of Metabolism, National Cancer Institute, National Institutes of Health, 37 Convent Drive, Bethesda, MD 20892, USA

'Division of Cardiology, The Second Hospital of Hebei Medical University, 215 Heping West Rd, Xinhua, Shijiazhuang, Hebei 050000, People's Republic of China
}

(c) The Author(s). 2017 Open Access This article is distributed under the terms of the Creative Commons Attribution 4.0 International License (http://creativecommons.org/licenses/by/4.0/), which permits unrestricted use, distribution, and reproduction in any medium, provided you give appropriate credit to the original author(s) and the source, provide a link to the Creative Commons license, and indicate if changes were made. The Creative Commons Public Domain Dedication waiver (http://creativecommons.org/publicdomain/zero/1.0/) applies to the data made available in this article, unless otherwise stated. peptides $[6,7]$ and sensitive cardiac troponins $[8,9]$ have been used to predict risk of CAD.

ß2-microglobulin (B2M), a low molecular-weight protein $(\sim 11,800 \mathrm{Da})$, is a component of the major histocompatibility complex (MHC) class I molecules on all nucleated cells [10]. Due to the rapid, simple, reliable, and inexpensive measurement of B2M, it is commonly used by clinicians to evaluate conditions such as: dialysis-related amyloidosis [11], human immunodeficiency virus (HIV) disease [12], myeloma [13], leukemia [14], and collagen disease [15]. B2M has been correlated to inflammatory diseases [16] and is also an estimator of the glomerular filtration rate (GFR) [17].

Recent studies have shown that circulating B2M is elevated in accordance with the acuteness of disease in peripheral arterial disease (PAD) patients [18-20]. High levels of serum B2M was also associated with adverse cardiovascular outcomes in patients with CAD [21, 22]. 
Aysegul Zumrutdal has reported B2M was positively correlated with the carotid intima-media thickness (C-IMT) in haemodialysis patients [23]. However, there is no confirming evidence of the relationship between serum B2M and the severity of CAD. In this study, we examined the relationship between the concentrations of serum B2M and severity of CAD.

\section{Methods}

\section{Study population}

Two thousand two-hundred consecutive subjects admitted to a university hospital with the suspected or already documented of CAD (included acute coronary syndrome and stable angina), who underwent selective coronary angiography (CAG) between June 2011 and July 2012, participated as the candidates for study. A self-administered questionnaire was conducted (covering items on demographic, disease history, cigarette and alcohol consumption (defined as one or more alcoholic drink per week)). Diabetes mellitus history was defined as a fasting plasma glucose level $>126 \mathrm{mg} / \mathrm{dL}$, or 2-h post-load blood sugar $>200 \mathrm{mg} / \mathrm{dL}$, or glycated hemoglobin $(\mathrm{A} 1 \mathrm{c}) \geq$ $6.5 \%$, or using anti-diabetic drugs. Hypertension was defined as systolic blood pressure $(\mathrm{SBP}) \geq 140 \mathrm{mmHg}$ or diastolic blood pressure (DBP) $\geq 90 \mathrm{mmHg}$ or taking anti-hypertensive medications.

A total of 390 subjects were excluded where blood samples were not measured, or a questionnaire was not completed. 1,810 subjects with serum $\beta 2$-microglobulin and creatinine levels were selected as candidates for further study. Among them, 48 subjects with creatinine levels of $\geq 115 \mathrm{umol} / \mathrm{L}$ were removed to exclude the subjects with possibility of renal dysfunction. Finally, 1,762 subjects were included in this study, with 403 non-CAD subjects (referred to those with normal coronary angiography or vessel stenosis $<50 \%$ ), and 1,359 CAD subjects (those with positive coronary artery angiography and vessel stenosis $\geq 50 \%$ ). This observational study complied with the tenets of the Declaration of Helsinki and was approved by Clinical Research Ethical Committee of Hebei Medical University. All informed consents were signed by participants before conducting.

\section{Laboratory analysis}

In all cases, blood samples were drawn following a minimum $12 \mathrm{~h}$ overnight fast. All the tests were performed using standard biochemical techniques to determine the following parameters: $\beta 2$-microglobulin (B2M, mg/L), triglyceride $(\mathrm{mmol} / \mathrm{L})$, total cholesterol $(\mathrm{mmol} / \mathrm{L})$, highdensity lipoprotein cholesterol (HDL-cholesterol, $\mathrm{mmol} / \mathrm{L}$ ), low-density lipoprotein cholesterol (LDL-cholesterol, $\mathrm{mmol} / \mathrm{L})$, apolipoprotein-A $(\mathrm{g} / \mathrm{L})$, apolipoprotein-B $(\mathrm{g} / \mathrm{L})$, fasting blood glucose $(\mathrm{mmol} / \mathrm{L})$, creatinine (umol/L), blood urea nitrogen (BUN, mmol/L), and uric acid (UA, umol/L).

\section{Coronary angiography}

Two experienced interventional cardiologists (M.D. and M.G.K.) measured quantitative coronary angiography using the standard Judkins approach. Both had no knowledge of subjects' clinical information. Two or more clinicians cross-checked the CAG reports and determined the degree of coronary stenosis according to the American Heart Association standards [24]. Coronary stenosis was determined to be significant at $\geq 50 \%$. Left anterior descending arteries, left circumflex arteries, and right coronary arteries were measured to determine the number and range of stenotic coronary arteries (SCA) (0 to 3-vessel disease (VD)). 2-VD was independently recorded when coronary stenosis was found in the left main trunk. Stenotic arteries was counted using the scoring systems, Gensini [25] and SYNTAX [26], to determine the extent of CAD.

\section{Statistical analysis}

All subjects were categorized into 4 groups according to $\mathrm{B} 2 \mathrm{M}$ quartile ranges. Data was presented as the mean $\pm \mathrm{SD}$ (standard deviation) for scaled measurements or percentages for categorized values. Analysis of variance (ANOVA) was performed for testing continuous data. Kruskal-Wallis test was used for not normally distributed outcomes. Categorical comparison was tested through Chi-square test. Pearson correlations and Spearman correlations were performed to determine statistically significant factors into multiple regression model. Biologically relevant factors were also selected into multiple regression model to exam the association between B2M and CAD as well as B2M and Gensini score or SYNTAX score. Receiver operating characteristics (ROC) curve was used to assess the prediction accuracy of CAD by B2M. Statistically significance was set as $P<0.05$. All the statistical analyses were conducted by Statistical Package for Social Sciences (SPSS) software (version 12 for Windows, SPSS, Inc., Chicago, IL, USA).

\section{Results}

Characteristics of the study subjects

One thousand seven hundred sixty-two subjects were eligible for the study (403 non-CAD subjects and 1,359 CAD subjects). CAD subjects were elder than non-CAD subject $(58.60 \pm 9.59$ vs $55.65 \pm 9.68, p<0.001)$. More males were observed in the CAD subjects $(70.6 \%$ vs $47.8 \%, p<0.001)$. The prevalence of smoking, drinking, hypertension, diabetes mellitus, and acute myocardial infarction (AMI) in CAD subjects was higher than non-CAD subjects (Table 1 ). CAD subjects also had a higher value of creatinine concentrations, blood urea nitrogen (BUN), uric acid (UA), triglyceride, apolipoprotein-A and apolipoprotein-B. B2M levels were significantly lower in non-CAD subjects $(1.14 \pm 0.28$ vs $1.25 \pm 0.46 \mathrm{mg} / \mathrm{L}, p<0.001$; Fig. 1a).

All 1,762 subjects were also categorized into 4 groups based on B2M quartile ranges (Additional file 1: Figure S1): 
Table 1 Clinical and biochemical characteristics of the study subjects

\begin{tabular}{|c|c|c|c|}
\hline & Non-CAD $(n=403)$ & $\operatorname{CAD}(n=1,359)$ & $p$-value \\
\hline Age (years) & $55.65 \pm 9.68$ & $58.60 \pm 9.59$ & $<0.001$ \\
\hline Gender (male, \%) & 47.8 & 70.6 & $<0.001$ \\
\hline Smoking (\%) & 18.9 & 39.4 & $<0.001$ \\
\hline Drinking (\%) & 15.9 & 25.8 & $<0.001$ \\
\hline Hypertension (\%) & 47.8 & 63.5 & $<0.001$ \\
\hline Diabetes (\%) & 9.2 & 19.4 & $<0.001$ \\
\hline AMI (\%) & 1.2 & 7.6 & $<0.001$ \\
\hline HF (\%) & 0.5 & 0.7 & 0.992 \\
\hline SBP & $131.54 \pm 18.56$ & $133.44 \pm 21.22$ & 0.108 \\
\hline DBP & $81.29 \pm 12.08$ & $81.15 \pm 20.89$ & 0.378 \\
\hline HR (bpm) & $68.04 \pm 14.68$ & $70.49 \pm 13.08$ & 0.008 \\
\hline Creatinine (umol/L) & $66.58 \pm 15.25$ & $71.2 \pm 15.3$ & $<0.001$ \\
\hline BUN (mmol/L) & $5.25 \pm 4.2$ & $6.38 \pm 18.96$ & $<0.001$ \\
\hline UA (umol/L) & $285.44 \pm 137.57$ & $306.84 \pm 179.28$ & $<0.001$ \\
\hline Glu & $7.44 \pm 31.96$ & $6.48 \pm 18.86$ & $<0.001$ \\
\hline TG (mmol/L) & $1.6 \pm 1.01$ & $2 \pm 5.19$ & 0.002 \\
\hline $\mathrm{TC}(\mathrm{mmol} / \mathrm{L})$ & $4.36 \pm 1.83$ & $4.67 \pm 11.29$ & 0.424 \\
\hline HDL-C (mmol/L) & $1.49 \pm 5.22$ & $1.09 \pm 0.45$ & 0.000 \\
\hline LDL-C (mmol/L) & $2.58 \pm 0.77$ & $2.95 \pm 9.76$ & 0.055 \\
\hline Apo-A (g/L) & $1.37 \pm 0.27$ & $1.3 \pm 0.71$ & $<0.001$ \\
\hline Apo-B (g/L) & $0.88 \pm 0.25$ & $1.15 \pm 4.9$ & $<0.001$ \\
\hline B2M (mg/L) & $1.14 \pm 0.28$ & $1.25 \pm 0.46$ & $<0.001$ \\
\hline Gensini score & $0.5 \pm 1.69$ & $39.34 \pm 34.66$ & $<0.001$ \\
\hline
\end{tabular}

$C A D$ coronary artery disease, $A M I$ acute myocardial infarction, $H F$ heart failure, $S B P$ systolic blood pressure, $D B P$ diastolic blood pressure, $H R$ heart rate, BUN blood urea nitrogen, UA uric acid, Glu blood glucose, TG Triglycerides, TC total cholesterol, HDL-C high-density lipoprotein cholesterol, $L D L-C$ low-density lipoprotein cholesterol, Apo-A Apolipoprotein A, Apo-B Apolipoprotein B, B2M $\beta 2$-microglobulin. Data are means \pm SD 1st quartile $(<1.00 \mathrm{mg} / \mathrm{L})$, 2nd quartile $(1.00-1.17 \mathrm{mg} / \mathrm{L})$, 3rd quartile (1.18-1.35 $\mathrm{mg} / \mathrm{L})$, and 4th quartile $(>1.35 \mathrm{mg} / \mathrm{L})$. To eliminate the possibility of renal dysfunction, subjects only in the normal range of creatinine were included (Additional file 2: Figure S2). As shown in Table 2, we compared the main baseline demographic, clinical and angiographic characteristics between the four quartiles. There was an increasing in B2M level with aging $(p<0.001)$. Significant measurements were also included drinking, hypertension, diabetes mellitus, myocardial infarction, baseline apolipoprotein-A, HDL-C, creatinine, uric acid (UA) and blood urea nitrogen (BUN) (Table 2).

\section{Relationship between serum B2M and prevalence of CAD}

In univariate analysis, age, gender, smoking, drinking, hypertension, diabetes mellitus and AMI were statistically associated with CAD. Further, clinical predictors (heart failure, hypertension and heart rate (HR)) and biochemical risk factors (creatinine, BUN, UA, TG, TC, HDLC, LDL-C, apolipoprotein-A, apolipoprotein-B, and B2M) were involved into multiple logistic regression model. After adjusted all the confounders, B2M (odds ratio, $\mathrm{OR}=2.363$, 95\% confidence interval $(\mathrm{CI}): 1.467-3.906, p=0.001)$, gender $(\mathrm{OR}=2.247, \mathrm{CI}: 1.668-3.041, p<0.001)$, age $(\mathrm{OR}=1.035$, CI: $1.021-1.050, p<0.001)$, smoking $(\mathrm{OR}=$ 1.865 , CI: $1.336-2.62, p<0.001)$, hypertension $(\mathrm{OR}=$ 1.382, CI: $1.074-1.792, p=0.014)$, diabetes $(\mathrm{OR}=2.278$, CI: $1.532-3.541, p<0.001)$, AMI (OR $=6.224$, CI: $2.272-$ $25.708, p=0.02)$ and HDL-C (OR $=0.626, \mathrm{CI}: 0.479$ $0.806, p<0.001$ ) were predictors of CAD (Table 3 ).

The correlation of $\mathrm{B} 2 \mathrm{M}$ levels and prevalence of CAD was further confirmed in all four quartiles of B2M levels (CAD prevalence in B2M quartiles: 68.1\% vs $75.7 \%$ vs $79.1 \%$ vs $86.1 \%$, OR $(95 \% \mathrm{CI})=1.432$ (1.288-1.602), $p<0.001$, Fig. 2a, Table 2). The positive

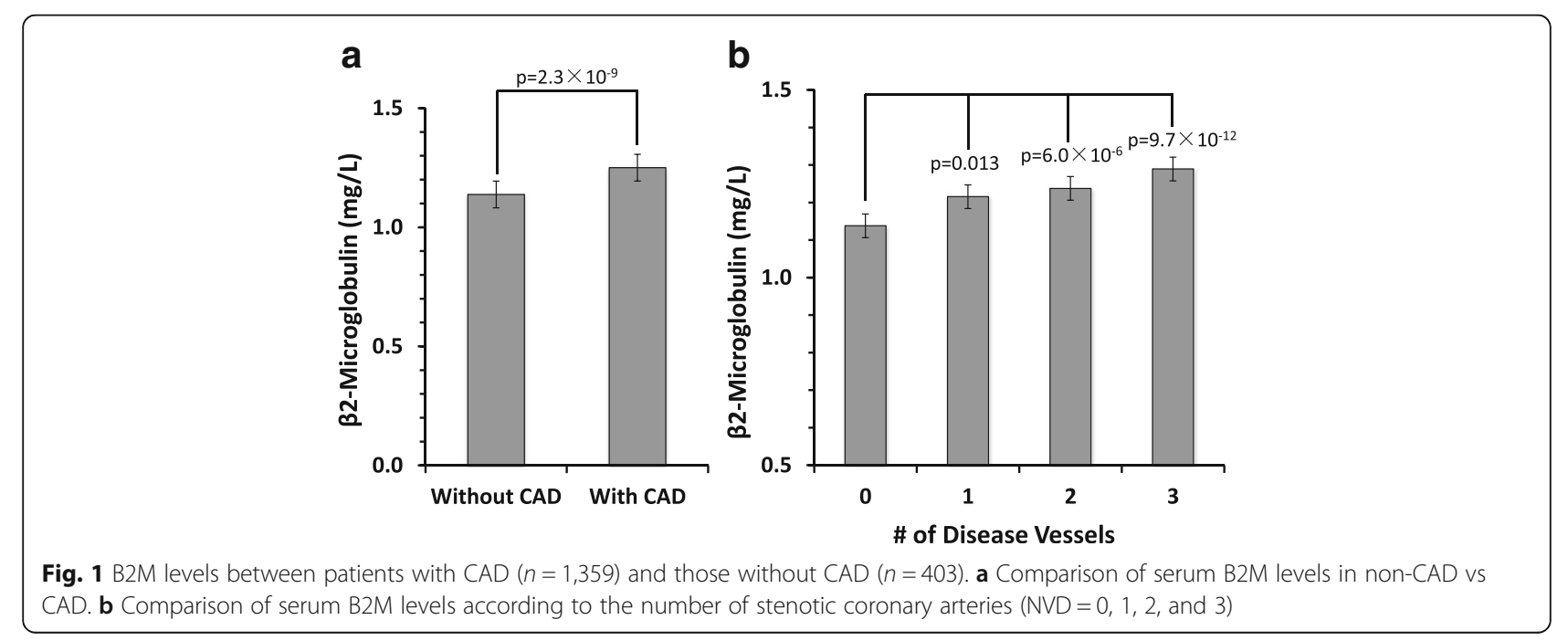


Table 2 Baseline clinical and angiographic features based on quartiles of B2M

\begin{tabular}{|c|c|c|c|c|c|}
\hline \multirow[t]{2}{*}{ Characteristics } & \multirow{2}{*}{$\begin{array}{l}\text { Quartile } 1 \\
\leq 1.00(\mathrm{mg} / \mathrm{L}) \\
n=472\end{array}$} & \multirow{2}{*}{$\begin{array}{l}\text { Quartile } 2 \\
1.00-1.17(\mathrm{mg} / \mathrm{L}) \\
n=443\end{array}$} & \multirow{2}{*}{$\begin{array}{l}\text { Quartile } 3 \\
1.18-1.35(\mathrm{mg} / \mathrm{L}) \\
n=431\end{array}$} & \multirow{2}{*}{$\begin{array}{l}\text { Quartile } 4 \\
>1.35(\mathrm{mg} / \mathrm{L}) \\
n=416\end{array}$} & \multirow[t]{2}{*}{$p$-value } \\
\hline & & & & & \\
\hline \multicolumn{6}{|l|}{ Baseline clinical features } \\
\hline Age (years) & $53.85 \pm 9.44$ & $56.49 \pm 9.12$ & $60.38 \pm 8.53$ & $61.58 \pm 9.55$ & $<0.001$ \\
\hline Gender (male, \%) & 63.0 & 68.7 & 65.8 & 63.9 & 0.285 \\
\hline Smoker (\%) & 33.3 & 38.3 & 34.9 & 32.0 & 0.242 \\
\hline Drinker (\%) & 25.5 & 28.0 & 21.7 & 18.3 & 0.005 \\
\hline Hypertension (\%) & 52.9 & 59.0 & 61.3 & 67.7 & $<0.001$ \\
\hline Diabetes (\%) & 15.2 & 16.0 & 15.5 & 22.1 & 0.022 \\
\hline AMI (\%) & 3.6 & 5.9 & 8.5 & 6.9 & 0.018 \\
\hline HF (\%) & 0.4 & 0.5 & 0.9 & 0.7 & 0.751 \\
\hline \multicolumn{6}{|l|}{ Baseline blood features } \\
\hline TG (mmol/L) & $1.86 \pm 1.33$ & $2.01 \pm 5.09$ & $2.12 \pm 7.51$ & $1.64 \pm 1.03$ & 0.228 \\
\hline TC $(\mathrm{mmol} / \mathrm{L})$ & $4.39 \pm 0.99$ & $4.42 \pm 1.01$ & $4.39 \pm 1.88$ & $5.26 \pm 20.39$ & 0.044 \\
\hline $\mathrm{HDL}-\mathrm{C}(\mathrm{mmol} / \mathrm{L})$ & $1.14 \pm 0.49$ & $1.38 \pm 4.98$ & $1.1 \pm 0.33$ & $1.09 \pm 0.58$ & 0.000 \\
\hline LDL-C (mmol/L) & $2.65 \pm 0.82$ & $2.74 \pm 0.92$ & $2.62 \pm 0.85$ & $3.49 \pm 17.6$ & 0.295 \\
\hline Apo-A (g/L) & $1.31 \pm 0.29$ & $1.41 \pm 1.15$ & $1.27 \pm 0.26$ & $1.25 \pm 0.38$ & $<0.001$ \\
\hline Apo-B (g/L) & $1.25 \pm 6.59$ & $1.19 \pm 5.19$ & $0.94 \pm 0.4$ & $0.94 \pm 0.36$ & 0.730 \\
\hline Creatinine (umol/L) & $64.13 \pm 13.68$ & $68.48 \pm 13.12$ & $71.36 \pm 15.56$ & $77.4 \pm 16.13$ & $<0.001$ \\
\hline BUN (mmol/L) & $5.78 \pm 14.45$ & $5.15 \pm 1.26$ & $6.89 \pm 19.98$ & $6.74 \pm 23.13$ & $<0.001$ \\
\hline UA (umol/L) & $272.97 \pm 76.96$ & $299.38 \pm 88.34$ & $300.06 \pm 120.89$ & $338.75 \pm 301.73$ & $<0.001$ \\
\hline \multicolumn{6}{|l|}{ Angiographic features } \\
\hline CAD (\%) & 68.1 & 75.7 & 79.1 & 86.1 & $<0.001$ \\
\hline Severe CAD $(\%)$ & 29.4 & 46.5 & 52.2 & 82.2 & $<0.001$ \\
\hline \multicolumn{2}{|c|}{ Number of stenotic arteries } & & & & $<0.001$ \\
\hline $0(\%)$ & 37.2 & 27.1 & 22.3 & 21.7 & \\
\hline $1(\%)$ & 26.6 & 28.0 & 25.6 & 21.3 & \\
\hline $2(\%)$ & 22.1 & 25.2 & 26.2 & 24.5 & \\
\hline $3(\%)$ & 14.1 & 19.8 & 25.9 & 32.6 & \\
\hline Gensini score & $24.94 \pm 31.95$ & $28.31 \pm 34.42$ & $30.02 \pm 32.54$ & $39.5 \pm 37.73$ & $<0.001$ \\
\hline
\end{tabular}

${ }^{a}$ Severe $C A D$ defined as the patients with number of stenotic arteries $\geq 2$. Data are means $\pm S D$

$C A D$ coronary artery disease, $A M I$ acute myocardial infarction, $H F$ heart failure, $S B P$ systolic blood pressure, $D B P$, diastolic blood pressure, $H R$ heart rate, $B U N$ blood urea nitrogen, UA uric acid, TG Triglycerides, TC total cholesterol, HDL-C high-density lipoprotein cholesterol, $L D L-C$ low-density lipoprotein cholesterol, $A p o-A$ Apolipoprotein A, Apo-B Apolipoprotein B, B2M $\beta 2$-microglobulin

trend was also observed with increased number of stenotic arteries ( $p<0.001$, Table 2, Additional file 3: Figure S3).

The ability of correctly diagnosing CAD and non-CAD subject according to B2M was assessed using the receiver operating characteristics (ROC) curve. B2M showed a moderate predictive ability for CAD according to the area under the ROC curve (AUC $=0.608,95 \% \mathrm{CI}$ : $0.577-0.639, p=0.001$ ) (Fig. 3).

\section{Relationship between serum B2M and clinical or biochemical parameters}

B2M was positively correlated with age (Pearson Correlation Coefficient $\left.\left(r_{p}\right) r_{p}=0.207, p<0.001\right)$, SBP $\left(r_{p}=0.073\right.$, $p=0.004)$, creatinine $\left(\mathrm{r}_{\mathrm{p}}=0.203, p<0.001\right)$ and UA $\left(\mathrm{r}_{\mathrm{p}}=0.113, p<0.001\right)($ Table 4). In multiple regression, age (standardized $\beta=0.197, p<0.001$ ), SBP (standardized $\beta=0.057, p=0.020$ ), creatinine (standardized $\beta=0.179$, $p<0.001$ ), and UA (standardized $\beta=0.095, p<0.001$ ) were still associated with B2M.

Relationship between serum B2M and severity of CAD B2M was positively correlated with Gensini score (Spearman Correlation Coefficient $\left(\mathrm{r}_{\mathrm{s}}\right) \mathrm{r}_{\mathrm{s}}=0.169, p<0.001$; Fig. 4a). We further assessed the relationship by a multiple stepwise regression model adjusting age, gender, smoking, hypertension, diabetes mellitus and AMI. 
Table 3 Multiple stepwise regression analysis showing variables independently associated with CAD

\begin{tabular}{lcll}
\hline & Odds Ratio (OR) & $95 \% \mathrm{Cl}$ & $p$-value \\
\hline B2M & 2.363 & $1.467-3.906$ & 0.001 \\
Gender & 2.247 & $1.668-3.041$ & $<0.001$ \\
Age & 1.035 & $1.021-1.050$ & $<0.001$ \\
Smoking & 1.865 & $1.336-2.620$ & $<0.001$ \\
Hypertension & 1.382 & $1.074-1.792$ & 0.014 \\
Diabetes & 2.278 & $1.523-3.514$ & $<0.001$ \\
AMl & 6.224 & $2.272-25.708$ & 0.002 \\
HDL-C & 0.626 & $0.479-0.806$ & $<0.001$ \\
\hline CADC
\end{tabular}

$C A D$ coronary artery disease, $B 2 M \beta 2$-microglobulin, $A M I$ acute myocardial infarction $H D L-C$ high-density lipoprotein cholesterol

After adjustment, serum B2M was still significantly associated with the Gensini score $(\beta=0.078,95 \% \mathrm{CI}$ : 0.029-0.127, $p=0.002$; Table 5).

We also performed the analysis in SYNTAX score. B2M was correlated with SYNTAX score $\left(r_{s}=0.239, p<0.001\right.$, Fig. 4b). In multiple stepwise regression, SYNTAX score was increased 0.077 as B2M level increased $1 \mathrm{mg} / \mathrm{L}$ $(\beta=0.077$, 95\% CI: 0.029-0.126, $p=0.002$; Table 6).

Proportion of severe CAD was increased with higher B2M levels $(29.4 \%$ vs $46.5 \%$ vs $52.2 \%$ vs $82.2 \%, p<0.001$, Fig. 2b, Table 2). B2M increased with the number of stenotic vessels with the lowest level in NVD of $0(1.14 \pm 0.28$, $1.22 \pm 0.61,1.24 \pm 0.32,1.29 \pm 0.39 \mathrm{mg} / \mathrm{L}$ in NVD of 0,1 , 2, and 3, respectively (Fig. 1b)).

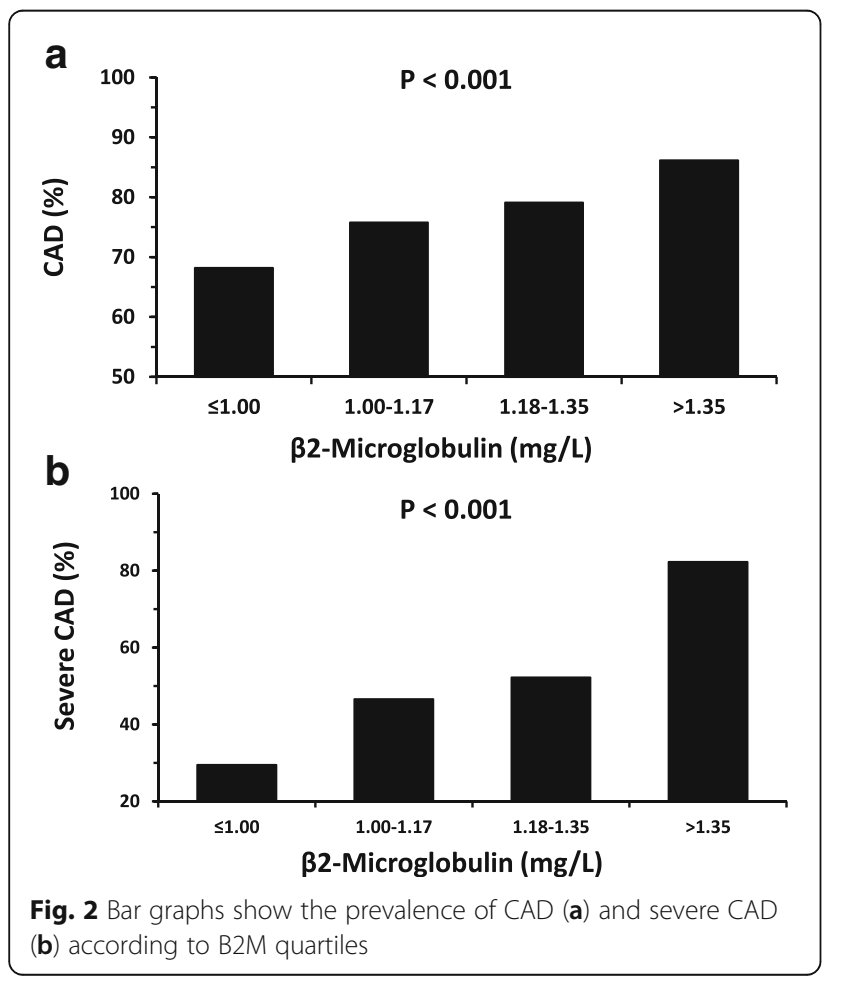

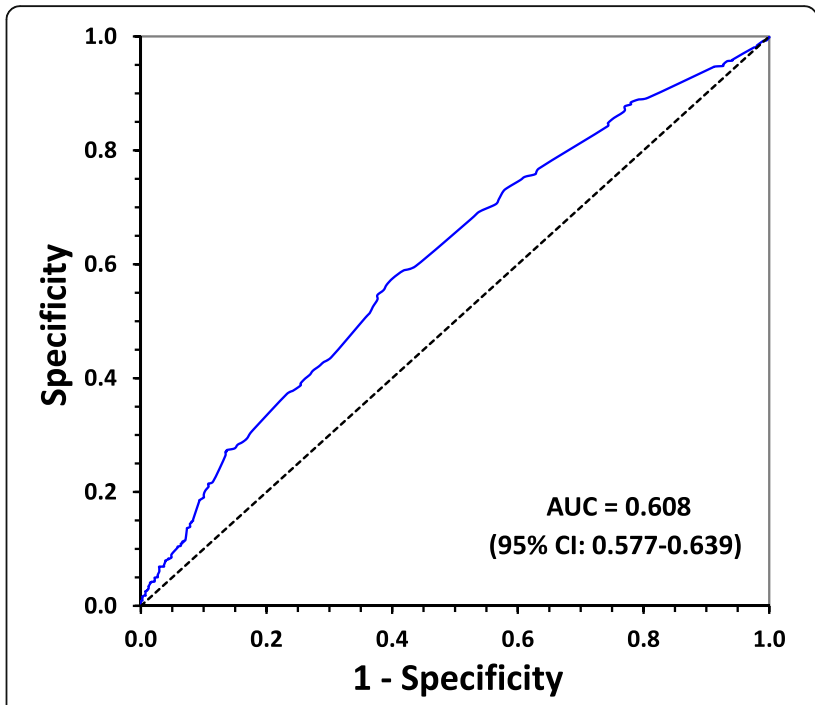

Fig. 3 ROC curve analyses for predictive values of B2M in detecting CAD

\section{Discussion}

Coronary artery disease (CAD) is associated with a high rate of mortality. Scientists and researchers have attempted to reduce the burden by identifying the relationship between biomarkers and CAD. In recent years, several biomarkers - C-reactive protein $[4,5]$, natriuretic peptides $[6,7]$ and sensitive cardiac troponins $[8,9]$ - have been used to estimate the risk of CAD. Some researchers have also investigated the relationship between coagulation factors (such as Fibrinogen, Thrombin, and Tissue

Table 4 Correlation of serum B2M with clinical and biochemical parameters

\begin{tabular}{lcc}
\hline Variables & $r$ & $p$-value \\
\hline Age & 0.207 & $<0.001$ \\
SBP & 0.073 & 0.004 \\
DBP & 0.005 & 0.833 \\
HR & 0.021 & 0.407 \\
Creatinine & 0.203 & 0.000 \\
BUN & 0.029 & 0.262 \\
UA & 0.113 & 0.000 \\
Glu & 0.004 & 0.877 \\
TG & -0.014 & 0.572 \\
TC & 0.033 & 0.195 \\
HDL-C & -0.016 & 0.519 \\
LDL-C & 0.010 & 0.683 \\
Apo-A & -0.037 & 0.149 \\
Apo-B & -0.008 & 0.749 \\
\hline SBP systolic blood pressure, DBP diastolic blood pressure, HR heart rate, BUN \\
blood urea nitrogen, UA uric acid, Glu blood glucose, TG Triglycerides, TC total \\
cholesterol, HDL-C high-density lipoprotein cholesterol, LDL-C low-density \\
lipoprotein cholesterol, Apo-A Apolipoprotein A, Apo-B Apolipoprotein B
\end{tabular}



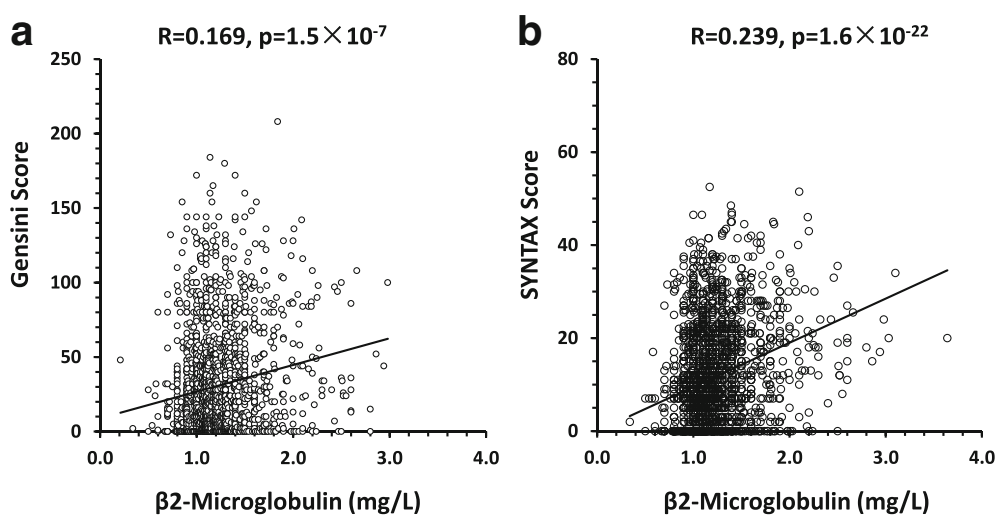

Fig. 4 Correlation between B2M and the severity of CAD evaluated by either (a) Gensini or (b) SYNTAX score

Factor), development of atherosclerosis and thrombotic complication $[27,28]$, so as to optimize the treatment of CAD patients.

This is the first study to reveal the effects of B2M plasmatic level in the extent of coronary atherosclerosis in a large consecutive Chinese population. Our study demonstrated the B2M was not only associated with CAD prevalence, but also positively correlated with severity of CAD. One study has reported the correlation between $\mathrm{B} 2 \mathrm{M}$ and carotid atherosclerosis severity in renal failure patients [23]. However, biased study population and limited the sample size constrained the conclusion to extend to other population.

The protein $\mathrm{B} 2 \mathrm{M}$ is a non-glycosylated polypeptide consisted of 99 amino acids, and it can interact with and stabilize the tertiary structure of the MHC I $\alpha$-chain [29]. B2M is not directly attached to cell membranes, due to its non-covalently association with the $\alpha$-chain. After released inside the cell or detached from cell surfaces, B2M is then largely removed via glomerular filtration. It is this process that allows the glomerular filtration rate to be estimated [30]. In comparison to healthy subjects (serum B2M $<2 \mathrm{ug} / \mathrm{mL}$, and urinary excretion <400ug/24 h [29]), patients on dialysis have greatly elevated B2M levels which contribute to amyloid

Table 5 Multiple stepwise regression analysis showing variables independently associated with Gensini score

\begin{tabular}{lcll}
\hline Variables & Coefficients $(\beta)$ & $95 \% \mathrm{Cl}$ & $p$-value \\
\hline B2M & 0.078 & $0.029-0.127$ & 0.0019 \\
Gender & 0.132 & $0.077-0.188$ & $<0.001$ \\
Age & 0.107 & $0.058-0.157$ & $<0.001$ \\
Smoking & 0.070 & $0.015-0.126$ & 0.0125 \\
Hypertension & 0.052 & $0.004-0.101$ & 0.0333 \\
AMl & 0.124 & $0.076-0.172$ & $<0.001$ \\
Diabetes & 0.105 & $0.057-0.153$ & $<0.001$
\end{tabular}

$B 2 M \beta 2$-microglobulin, $A M I$ acute myocardial infarction deposition and cardiovascular dysfunction [31]. Autoimmune, neoplastic, and infectious diseases, such as multiple myeloma, lymphoma, and Sjogren's syndrome have also reported to associate with increased plasma levels of B2M [32-34].

Although the mechanism for the association between B2M levels and CAD remains to be clarified, the relationship between B2M and alterations in vascular structures, immunity and inflammation disorders, suggests B2M may contribute to vascular inflammation [35, 36]. Atherosclerotic syndromes are also predominantly associated with an inflammatory response [37, 38], which leads the relationship between B2M and CAD. Furthermore, studies have shown that B2M concentrations were significant non-renal predictors of cardiovascular outcomes, renal outcomes, and mortality [39-43].

Researchers have provided association between B2M and CAD risk factors [22, 35], and left atrial size [44]. Liu YS found a positive relationship of B2M to serum levels of creatinine and a negative relationship to creatinine clearance rate [44]. To further build on these studies, we divided the participants into four quartiles according to the serum B2M levels, as well as the number of SCA (0 to $3-\mathrm{VD})$. We observed the B2M level was remarkably associated with the prevalence

Table 6 Multiple stepwise regression analysis showing variables independently associated with Syntax score

\begin{tabular}{lcll}
\hline Variables & Coefficients $(\beta)$ & $95 \% \mathrm{Cl}$ & $p$-value \\
\hline B2M & 0.077 & $0.029-0.126$ & 0.0018 \\
Gender & 0.160 & $0.105-0.215$ & $<0.001$ \\
Age & 0.154 & $0.104-0.203$ & $<0.001$ \\
Smoking & 0.049 & $-0.006-0.103$ & 0.0802 \\
Hypertension & 0.062 & $0.014-0.109$ & 0.0114 \\
AMl & 0.149 & $0.101-0.196$ & $<0.001$ \\
Diabetes & 0.109 & $0.061-0.156$ & $<0.001$ \\
\hline
\end{tabular}

B2M $\beta 2$-microglobulin, AMI acute myocardial infarction 
of severe CAD (29.4\% for B2M $\leq 1 \mathrm{mg} / \mathrm{L}$, while $82.2 \%$ for $\mathrm{B} 2 \mathrm{M}>1.35 \mathrm{mg} / \mathrm{L})$. Another important observation was that the B2M level was positively correlated with creatinine, especially in the subjects with severe CAD. Liu YS also found a linear trend between uric acid and $\mathrm{B} 2 \mathrm{M}$, indicating a potential link between the kidney and the heart [44].

There were some limitations in this study. First, we did not have a control group for the CAD or suspected diagnosis of CAD. Although the participants with number of SCA of 0 were treated as control group (non-CAD), all subjects in our study were consecutive at least with the suspected diagnosis of CAD. Therefore, the control group participants may be with a high risk for CAD. Second, this is an observational study, the follow up outcomes of B2M levels on cardiovascular was unavailable.

Our study reveals a strong association between level of serum B2M and CAD (both prevalence and severity) in subjects without renal dysfunction. These findings provide support to the potential of $\mathrm{B} 2 \mathrm{M}$ as a biomarker for CAD. Further studies are need to ensure the potential benefits of $\mathrm{B} 2 \mathrm{M}$ level for $\mathrm{CAD}$ in clinical routine.

\section{Conclusions}

The significant association between serum B2M and CAD suggests that $\mathrm{B} 2 \mathrm{M}$ could be a biomarker for CAD.

\section{Additional files}

Additional file 1: Figure S1. The distribution of concentrations of B2M in all 1,762 subjects. (PPT $91 \mathrm{~kb}$ )

Additional file 2: Figure S2. The distribution of creatinine levels in all 1,762 subjects. (PPT $88 \mathrm{~kb}$ )

Additional file 3: Figure S3. The number of stenotic arteries in each quartile by B2M levels. (PPT $79 \mathrm{~kb}$ )

\section{Acknowledgements}

Our appreciation for the participants of this research and colleagues who assisted throughout the study. In particular, we thank Dr. Lei Zheng for statistics assistance.

\section{Funding}

This work was generously supported by grants from the Science and technology project of Hebei Province (Grant No. 15277715D to Ling You) and grants from the key project of medical science research in Hebei Province in 2015 (Grant No. 20150208 to Ling You).

\section{Availability of data and materials}

The datasets supporting the conclusions of this article are included within the article.

\section{Authors' contributions}

L.Y. participated in the design, performed the experiment, collected the data, performed statistical analyses and drafted the manuscript. X.H. participated in the design, performed statistical analyses and helped to draft the manuscript. W.C. and R.X. participated in the design, performed statistical analyses. H.H., G.G., J.Z., H.Z. and X.Y. performed the experiment and collected the data. All authors read and approved the final manuscript.

\section{Competing interests}

The authors declare that they have no competing interests.

\section{Consent for publication}

Not applicable.

\section{Ethics approval and consent to participate}

The study protocol complied with the Declaration of Helsinki and was approved by Clinical Research Ethical Committee of Hebei Medical

University. Written informed consent was obtained from all subjects.

Received: 2 July 2016 Accepted: 14 February 2017

Published online: 01 March 2017

\section{References}

1. Hemingway H, McCallum A, Shipley M, Manderbacka K, Martikainen P, Keskimaki I. Incidence and prognostic implications of stable angina pectoris among women and men. JAMA. 2006;295(12):1404-11.

2. Finegold JA, Asaria P, Francis DP. Mortality from ischaemic heart disease by country, region, and age: statistics from World Health Organisation and United Nations. Int J Cardiol. 2013;168(2):934-45.

3. Beltrame JF, Weekes AJ, Morgan C, Tavella R, Spertus JA. The prevalence of weekly angina among patients with chronic stable angina in primary care practices: The Coronary Artery Disease in General Practice (CADENCE) Study. Arch Intern Med. 2009;169(16):1491-9.

4. Haverkate F, Thompson SG, Pyke SD, Gallimore JR, Pepys MB. Production of C-reactive protein and risk of coronary events in stable and unstable angina. European Concerted Action on Thrombosis and Disabilities Angina Pectoris Study Group. Lancet. 1997;349(9050):462-6.

5. Dibra A, Mehilli J, Braun S, Hadamitzky M, Baum H, Dirschinger J, Schuhlen H, Schomig A, Kastrati A. Association between C-reactive protein levels and subsequent cardiac events among patients with stable angina treated with coronary artery stenting. Am J Med. 2003;114(9):715-22.

6. Kragelund C, Gronning B, Kober L, Hildebrandt P, Steffensen R. N-terminal pro-B-type natriuretic peptide and long-term mortality in stable coronary heart disease. N Engl J Med. 2005;352(7):666-75.

7. Ndrepepa G, Braun S, Niemoller K, Mehilli J, von Beckerath N, von Beckerath $\mathrm{O}$, Vogt W, Schomig A, Kastrati A. Prognostic value of N-terminal pro-brain natriuretic peptide in patients with chronic stable angina. Circulation. 2005; 112(14):2102-7.

8. Omland T, de Lemos JA, Sabatine MS, Christophi CA, Rice MM, Jablonski KA, Tjora S, Domanski MJ, Gersh BJ, Rouleau JL, et al. A sensitive cardiac troponin T assay in stable coronary artery disease. N Engl J Med. 2009; 361(26):2538-47.

9. Ndrepepa G, Braun S, Mehilli J, Birkmeier KA, Byrne RA, Ott I, Hosl K, Schulz S, Fusaro M, Pache J, et al. Prognostic value of sensitive troponin T in patients with stable and unstable angina and undetectable conventional troponin. Am Heart J. 2011:161(1):68-75.

10. Gussow D, Rein R, Ginjaar I, Hochstenbach F, Seemann G, Kottman A, Ploegh HL. The human beta 2-microglobulin gene. Primary structure and definition of the transcriptional unit. J Immunol. 1987;139(9):3132-8.

11. Winchester JF, Salsberg JA, Levin NW. Beta-2 microglobulin in ESRD: an in-depth review. Adv Ren Replace Ther. 2003;10(4):279-309.

12. Ullum H, Lepri AC, Katzenstein TL, Phillips AN, Skinhoj P, Gerstoft J, Pedersen BK. Prognostic value of single measurements of beta-2microglobulin, immunoglobulin A in HIV disease after controlling for CD4 lymphocyte counts and plasma HIV RNA levels. Scand J Infect Dis. 2000; 32(4):371-6

13. Diem H, Fateh-Moghadam A, Lamerz R. Prognostic factors in multiple myeloma: role of beta 2-microglobulin and thymidine kinase. Clin Investig. 1993;71(11):918-23.

14. Sadamori N, Mine M, Hakariya S, Ichiba M, Kawachi T, Itoyama T, Nakamura H, Tomonaga M, Hayashi K. Clinical significance of beta 2-microglobulin in serum of adult T cell leukemia. Leukemia. 1995;9(4):594-7.

15. Castro J, Jimenez-Alonso J, Sabio JM, Rivera-Civico F, Martin-Armada M, Rodriguez MA, Jaimez L, Castillo MJ, Sanchez-Roman J. Salivary and serum beta2-microglobulin and gamma-glutamyl-transferase in patients with primary Sjogren syndrome and Sjogren syndrome secondary to systemic lupus erythematosus. Clin Chim Acta. 2003;334(1-2):225-31.

16. Bethea M, Forman DT. Beta 2-microglobulin: its significance and clinical usefulness. Ann Clin Lab Sci. 1990;20(3):163-8. 
17. Jovanovic D, Krstivojevic P, Obradovic I, Durdevic V, Dukanovic L. Serum cystatin $\mathrm{C}$ and beta2-microglobulin as markers of glomerular filtration rate. Ren Fail. 2003;25(1):123-33.

18. Wilson AM, Kimura E, Harada RK, Nair N, Narasimhan B, Meng XY, Zhang F, Beck KR, Olin JW, Fung ET, et al. Beta2-microglobulin as a biomarker in peripheral arterial disease: proteomic profiling and clinical studies. Circulation. 2007;116(12):1396-403.

19. Fung ET, Wilson AM, Zhang F, Harris N, Edwards KA, Olin JW, Cooke JP. A biomarker panel for peripheral arterial disease. Vasc Med. 2008;13(3):217-24.

20. Cooke JP, Wilson AM. Biomarkers of peripheral arterial disease. J Am Coll Cardiol. 2010;55(19):2017-23.

21. Nead KT, Zhou MJ, Caceres RD, Sharp SJ, Wehner MR, Olin JW, Cooke JP, Leeper NJ. Usefulness of the addition of beta-2-microglobulin, cystatin C and C-reactive protein to an established risk factors model to improve mortality risk prediction in patients undergoing coronary angiography. Am J Cardiol. 2013;111(6):851-6.

22. Prentice RL, Paczesny S, Aragaki A, Amon LM, Chen L, Pitteri SJ, Mclntosh M, Wang P, Buson Busald T, Hsia J, et al. Novel proteins associated with risk for coronary heart disease or stroke among postmenopausal women identified by in-depth plasma proteome profiling. Genome Med. 2010;2(7):48.

23. Zumrutdal A, Sezer S, Demircan S, Seydaoglu G, Ozdemir FN, Haberal M. Cardiac troponin I and beta 2 microglobulin as risk factors for early-onset atherosclerosis in patients on haemodialysis. Nephrology. 2005;10(5):453-8.

24. Austen WG, Edwards JE, Frye RL, Gensini GG, Gott VL, Griffith LS, McGoon DC, Murphy ML, Roe BB. A reporting system on patients evaluated for coronary artery disease. Report of the Ad Hoc Committee for Grading of Coronary Artery Disease, Council on Cardiovascular Surgery, American Heart Association. Circulation. 1975;51(4 Suppl):5-40.

25. Gensini GG. A more meaningful scoring system for determining the severity of coronary heart disease. Am J Cardiol. 1983;51(3):606.

26. Garg S, Sarno G, Serruys PW, Rodriguez AE, Bolognese L, Anselmi M, De Cesare N, Colangelo S, Moreno R, Gambetti S, et al. Prediction of 1 -year clinical outcomes using the SYNTAX score in patients with acute ST-segment elevation myocardial infarction undergoing primary percutaneous coronary intervention: a substudy of the STRATEGY (Single High-Dose Bolus Tirofiban and Sirolimus-Eluting Stent Versus Abciximab and Bare-Metal Stent in Acute Myocardial Infarction) and MULTISTRATEGY (Multicenter Evaluation of Single High-Dose Bolus Tirofiban Versus Abciximab With Sirolimus-Eluting Stent or Bare-Metal Stent in Acute Myocardial Infarction Study) trials. JACC Cardiovasc Interv. 2011:4(1):66-75.

27. Campo G, Pavasini R, Pollina A, Tebaldi M, Ferrari R. Coagulation factors and recurrence of ischemic and bleeding adverse events in patients with acute coronary syndromes. Thromb Res. 2013;132(2):151-7.

28. Campo G, Valgimigli M, Ferraresi P, Malagutti P, Baroni M, Arcozzi C, Gemmati D, Percoco G, Parrinello G, Ferrari R, et al. Tissue factor and coagulation factor VII levels during acute myocardial infarction: association with genotype and adverse events. Arterioscler Thromb Vasc Biol. 2006; 26(12):2800-6.

29. Braciale TJ. Antigen processing for presentation by MHC class I molecules. Curr Opin Immunol. 1992;4(1):59-62.

30. Acchiardo S, Kraus Jr AP, Jennings BR. Beta 2-microglobulin levels in patients with renal insufficiency. Am J Kidney Dis. 1989;13(1):70-4.

31. Takayama F, Miyazaki S, Morita T, Hirasawa Y, Niwa T. Dialysis-related amyloidosis of the heart in long-term hemodialysis patients. Kidney Int Suppl. 2001;78:S172-176.

32. Alexanian R, Barlogie B, Fritsche $H$. Beta 2 microglobulin in multiple myeloma. Am J Hematol. 1985;20(4):345-51.

33. Cooper EH, Plesner T. Beta-2-microglobulin review: its relevance in clinical oncology. Med Pediatr Oncol. 1980;8(4):323-34.

34. Michalski JP, Daniels TE, Talal N, Grey HM. Beta2 microglobulin and lymphocytic infiltration in Sjogren's syndrome. N Engl J Med. 1975;293(24):1228-31.

35. Saijo Y, Utsugi M, Yoshioka E, Horikawa N, Sato T, Gong Y, Kishi R. Relationship of beta2-microglobulin to arterial stiffness in Japanese subjects. Hypertens Res. 2005;28(6):505-11.

36. Tzoulaki I, Murray GD, Lee AJ, Rumley A, Lowe GD, Fowkes FG. C-reactive protein, interleukin-6, and soluble adhesion molecules as predictors of progressive peripheral atherosclerosis in the general population: Edinburgh Artery Study. Circulation. 2005:112(7):976-83.

37. Libby P. Inflammation in atherosclerosis. Nature. 2002;420(6917):868-74.

38. Libby P, Ridker PM, Maseri A. Inflammation and atherosclerosis. Circulation. 2002;105(9):1135-43
39. Astor BC, Shafi T, Hoogeveen RC, Matsushita K, Ballantyne CM, Inker LA, Coresh J. Novel markers of kidney function as predictors of ESRD, cardiovascular disease, and mortality in the general population. Am J Kidney Dis. 2012;59(5):653-62.

40. Astor BC, Shaikh S, Chaudhry M. Associations of endogenous markers of kidney function with outcomes: more and less than glomerular filtration rate. Curr Opin Nephrol Hypertens. 2013;22(3):331-5.

41. Kals J, Zagura M, Serg M, Kampus P, Zilmer K, Unt E, Lieberg J, Eha J, Peetsalu A, Zilmer M. beta2-microglobulin, a novel biomarker of peripheral arterial disease, independently predicts aortic stiffness in these patients. Scand J Clin Lab Invest. 2011;71(4):257-63.

42. Amighi J, Hoke M, Mlekusch W, Schlager O, Exner M, Haumer M, Pernicka E, Koppensteiner R, Minar E, Rumpold H, et al. Beta 2 microglobulin and the risk for cardiovascular events in patients with asymptomatic carotid atherosclerosis. Stroke. 2011;42(7):1826-33.

43. Shinkai S, Chaves PH, Fujiwara Y, Watanabe S, Shibata H, Yoshida H, Suzuki T. Beta2-microglobulin for risk stratification of total mortality in the elderly population: comparison with cystatin C and C-reactive protein. Arch Intern Med. 2008;168(2):200-6.

44. Liu YS, Wang $X$, Jiang WD, Huang ZW, Wang YM, Hao L, Xing JL, Wang $L$, Liu XX, Lounsbury $P$, et al. Circulating levels of beta2-microglobulin and cystatin $C$ are associated with left atrial size: additional link between the kidney and the heart. Clin Nephrol. 2013;80(3):168-76.

\section{Submit your next manuscript to BioMed Central and we will help you at every step:}

- We accept pre-submission inquiries

- Our selector tool helps you to find the most relevant journal

- We provide round the clock customer support

- Convenient online submission

- Thorough peer review

- Inclusion in PubMed and all major indexing services

- Maximum visibility for your research

Submit your manuscript at www.biomedcentral.com/submit

) Biomed Central 